\title{
DEVELOPMENT OF SEA ICE IN THE WEDDELL SEA
}

by

\author{
M.A. Lange,
}

(Alfred-Wegener-Institut für Polar- und Meeresforschung, Postfach 120161, D-2850 Bremerhaven, Federal Republic of Germany)

S.F. Ackley,

(U.S. Army Cold Regions Research and Engineering Laboratory, 72 Lyme Road, Hanover, NH 03755, U.S.A.)

P. Wadhams,

(Scott Polar Research Institute, University of Cambridge, Lensfield Road, Cambridge CB2 1ER, England, U.K.)

\section{G.S. Dieckmann, and H. Eicken}

(Alfred-Wegener-Institut für Polar- und Meeresforschung, Postfach 120161, D-2850 Bremerhaven, Federal Republic of Germany)

\section{ABSTRACT}

We report on the development and physical properties of sea ice in the central and eastern Weddell Sea. The investigations were part of the Winter Weddell Sea Project 1986, which extended over the months of July through December. Major elements of the glaciological part of this study included continuous shipborne observations of sea-ice conditions and occasional helicopter reconnaissance flights, extensive measurements of snow and ice thicknesses at daily ice stations, and detailed analyses of sampled ice cores from each ice station. Textural investigations of the sampled ice revealed the dominance of frazil ice in the central Weddell Sea and the occurrence of an additional ice class, called platelet ice, together with the commonly known frazil and congelation ice in the coastal region of the eastern Weddell Sea. These results, in combination with the visual ice observations, reveal two major mechanisms for sea-ice generation in the Antarctic, which were not sufficiently well accounted for in previous investigations. In the central Weddell Sea, a cycle of pancake-ice formation and its growth into consolidated floes seems to be the dominant process of the advancing sea-ice edge. In the coastal waters, the growing sea-ice cover consists, to a considerable degree, of ice platelets which are formed in the underlying water column in front of the ice-shelf edges. Thus, congelation-ice growth, which is mainly controlled by atmospheric, thermodynamic forcing, seems to be of less importance in the central and south-eastern Weddell Sea than, for example, in the Arctic Basin.

\section{INTRODUCTION}

Sea ice constitutes a major element in the atmospheric, oceanographic, and biological regimes of the polar regions. An existing sea-ice cover will greatly reduce transfer of energy and matter between atmosphere and ocean. At the same time, sea ice provides a shelter for a particularly adapted group of micro-organisms, allowing them to survive the winter months (Garrison and others, 1986). A remarkable seasonal variation in the areal extent of the Antarctic sea-ice cover, ranging from a minimum of about $4 \times 10^{6} \mathrm{~km}^{2}$ to a maximum of over $20 \times 10^{6} \mathrm{~km}^{2}$, introduces strongly varying boundary conditions on each of these regimes (Ackley, 1981). An adequate assessment of basic sea-ice properties throughout the complete annual cycle is a nesessary prerequisite for an understanding of their effects on the polar environment.

Until recently, remote-sensing data and continuous observations at a few over-wintering stations around the Antarctic continent provided the only reliable source of information on Antarctic sea ice throughout the year. Additional sampling was mostly done during the austral summer months at a few selected sites in the Antarctic circumpolar waters (e.g. Gow and others, 1987; Lange, 1988). However, only the remains of the previously existing winter ice and land-fast, multi-year ice can be sampled at that point in the sea-ice cycle.

The Winter Weddell Sea Project 1986 on RV Polarstern (in the following abbreviated as WWSP 86), an international, multi-disciplinary program to study the winter conditions in the central and eastern Weddell Sea offered a rare opportunity to investigate major characteristics of Antarctic sea ice in the austral winter. The observations cover the central region from about $10^{\circ} \mathrm{W}$ to $10^{\circ} \mathrm{E}$ and $58^{\circ}$ to $70^{\circ} \mathrm{S}$ in the months from July through September (leg 1) and a near-shore area along the ice-shelf edges in the Weddell Sea from about $8^{\circ}$ to $32^{\circ} \mathrm{W}$ from September through early December (leg 2; Fig. 1).

In this paper, we describe major findings with regard to the development and properties of Antarctic sea ice in the Weddell Sea, focusing on the results obtained by continuous visual ice observations as well as textural studies of collected sea-ice cores. Although the study area covers only parts of the Antarctic circumpolar waters, we believe that our observations have a bearing on the development of Antarctic sea ice in general

\section{OBSERVATIONS AND ANALYSES}

On entering the ice-covered waters on both legs of WWSP 86, a continuous ice-observation program was set up. It consisted of an hourly assessment of current ice and snow conditions in the vicinity of the ship, including estimates of thickness (on broken and rafted floes), surface morphology, floe diameter, ice types, and the percentage of open water. At the time of the observation, two photographs were taken simultaneously, one from the starboard and one from the port side of the ship, providing some objective control on the narrative observations (Casarini and Massom, 1987; paper in preparation by M.A. Lange and H. Eicken). The shipborne observations were 


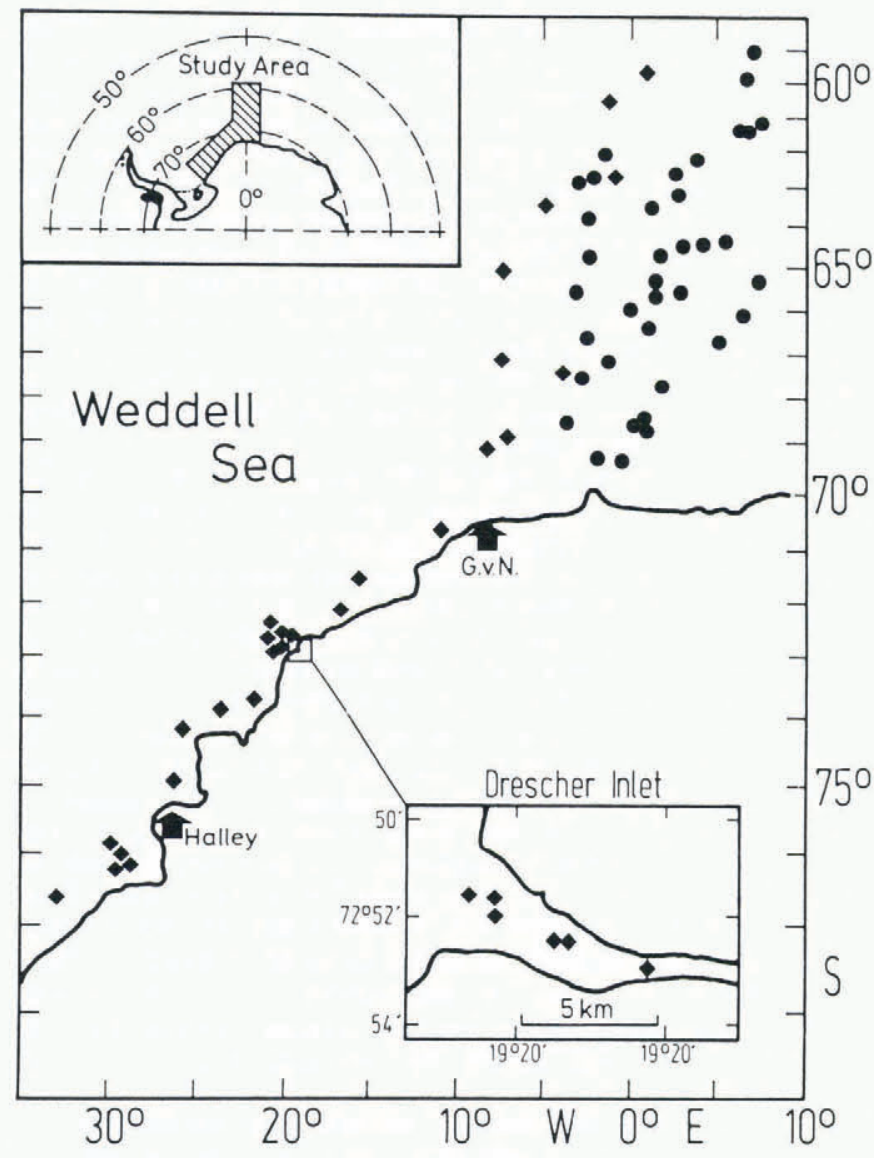

Fig. 1. Geographical positions of ice stations on leg 1 (•) and leg $2(\$)$ of the Winter Weddell Sea Project 1986.

supplemented by occasional helicopter reconnaissance flights, allowing the assessment of ice conditions in an area of about $50-100 \mathrm{~km}$ around the ship.

Each day, during the course through the ice, ice-station work was performed, resulting in a geographical coverage of at least one station per degree of latitude (about $100 \mathrm{~km}$ apart) on leg 1 and at a variable station spacing on leg 2 of WWSP 86 (Fig. 1). Work at each station included drilling of between three and five cores in close proximity to each other, in-situ measurements of ice temperature and light attentuation in the bore hole, sampling of the snow cover, and on-site characterization of its physical properties. In addition, we measured the ice and snow thicknesses along two sections, mostly oriented perpendicular to each other, giving approximately 80-100 thicknesses at each site (Wadhams and others, 1988).

The cores collected from each station were subsequently analyzed in a mobile cold laboratory on board Polarstern. Apart from a number of measurements and experiments performed on cores selected exclusively for this task, the bulk of the analyses were done on a randomly selected single core. This included an assessment of ice texture and measurements of physical, chemical, and biological properties on core sections whose spacing was selected on the basis of structural units (Lange, 1988). In order to assess ice texture, continuous thick sections were first cut along the entire length of the core. Whenever desirable, the thick sections were reduced to $0.7 \mathrm{~mm}$ thin sections using a microtome. In addition, we also obtained horizontal thin sections at selected depths within the cores. They were used to perform petrofabric measurements in order to obtain the distribution of $c$-axis orientations, thus aiding in the classification of the sampled ice floe.

The assessment of the physical nature of a sampled floe involves two steps. Thick- and thin-section analysis along the entire length of the core leads to the designation of distinct textural units by means of a textural classification scheme. Secondly, depending on the relative proportion of each textural class in a particular core, the development of the sampled floe is characterized, on the basis of a genetic classification.

We distinguish three textural ice classes: granular ice, columnar ice, and mixed granular/columnar ice, which have been described, for example, by Clarke and Ackley (1984) and Gow and others (1987). The classification of each ice core into categories related to the varying proportions of the three textural ice classes, resulted in differentiating five genetic ice classes: predominantly and mainly frazil ice (ice cores containing more than 80 or $60 \%$ granular ice, respectively), predominantly and mainly congelation ice (cores with more than 80 or $60 \%$ columnar ice, respectively), and mixed frazil/congelation ice (cores containing more than $40 \%$ of both granular and columnar ice) (paper in preparation by M.A. Lange and others). Genetic classification of cores from each ice station yielded maps of ice types as a function of geographical position in the area covered by the two legs of WWSP 86 .

\section{RESULTS}

\section{Leg 1 , central Weddell Sea}

Figure 2 gives the geographical distribution of genetic ice classes as observed during the first leg of WWSP 86. Relative fractions of each of the genetic ice classes observed on the first leg of WWSP 86 are 16.7 and $16.7 \%$ for both the predominantly and mainly congelation ice, 21.4 and $26.2 \%$ for the predominantly and mainly frazil ice, and $19.0 \%$ for the mixed frazil/congelation ice, respectively. The overall distribution is $57.1 \%$ frazil and $42.9 \%$ congelation ice (dividing the mixed frazil/congelation component into two equal parts). This is almost identical to the conclusion of Gow and others (1987) from observations in the extreme western Weddell Sea, which resulted in an overall distribution of $57.4 \%$ frazil versus $42.5 \%$ congelation ice (by again subdividing the mixed fraction into equal parts).

At first sight, there appears to be no significant correlation between ice classes and latitude. However, a closer look, in combination with the results obtained from

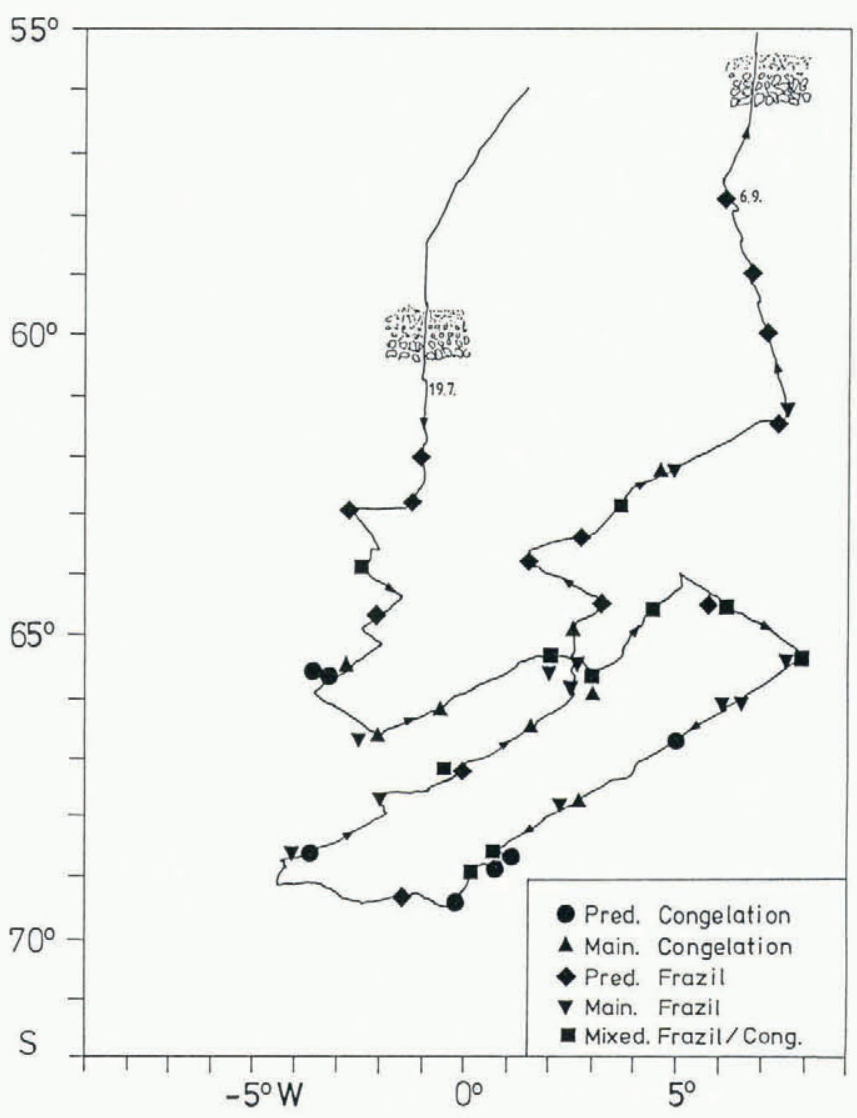

Fig. 2. Geographic positions of sampled floes of specific genetic ice class, as defined in the text, on leg 1 of WWSP 86 
the ice observations (Casarini and Massom, 1987), reveals interesting trends. As can be seen, there is a fairly obvious dominance of the predominantly and mainly frazil ice types from the northern ice edge to about $64^{\circ} \mathrm{S}$. On the basis of our observations, we conclude that this is caused mainly by the fact that we sampled ice of the advancing ice edge southward up to this position. This ice is mainly derived by the consolidation of pancake ice, which appears to dominate the growth cycle of sea ice in the central Weddell Sea (Ackley and others, 1986; Lange and others, 1986). Pancake ice consists of an agglomerated mixture of ice crystals and ice platelets initially suspended in the uppermost part of the water column. Wind and wave action gives rise to a gradual accumulation of suspended material into nearly circular discs some centimeters to tens of centimeters in diameter and several centimeters in thickness, which become mechanically intact units. Their texture reflects this mode of formation and matches best the granular-ice category (Weeks and Ackley, 1982). In the Weddell Sea, the pancakes gradually adhere to each other, slowly growing into aggregates of increasing size (Fig. 3). This process continues until these aggregates form a continuous, consolidated ice cover, up to

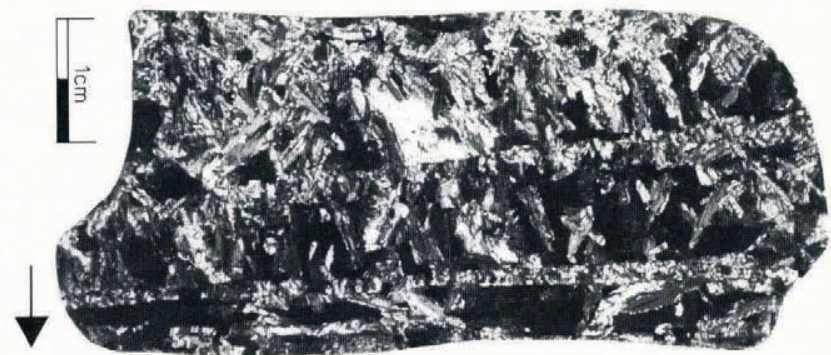

Fig. 3. Vertical thin-section photograph of a single pancake-ice disc as seen between crossed polarizers; here, as in the following photographs, the scale is in centimeters; the arrow points towards the bottom of the sampled floe.

some tens of centimeters in thickness. However, wind and wave action also gives rise to divergence and leads to rafting of parts of this ice cover on time-scales of the passage of the waves (tens of seconds). Since, at this point in the developmental cycle, the ice cover is still relatively close to the advancing ice edge, the opening leads are quickly filled by newly formed pancakes, which again form a consolidated cover. This process, which we call the "pancake cycle" (Fig. 4), is limited by two factors. On the one hand, the further the ice cover is from the ice edge,

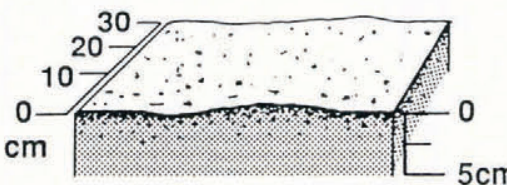

New Ice Formation Frazil lce

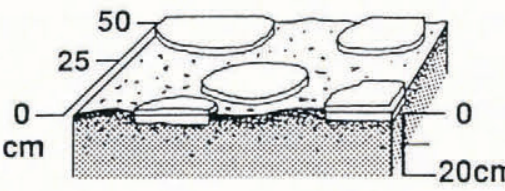

\section{Formation of Pancake Ice}

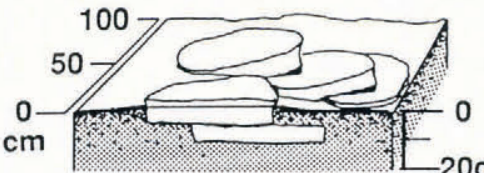

Freezing Together and Rafting of Pancake Ice

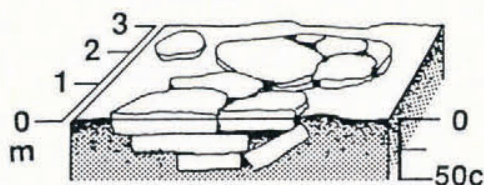

\section{Further Rafting and New Ice Formation}

Fig. 4. Schematic representation of the "pancake cycle" (see text for further details). the more efficient the attentuation of incident surface waves, thus preventing even more so the relative movement of existing floes (Squire and others, 1986). Based on our observations and the ice-thickness record (Wadhams and others, 1988), we conclude that this effectively limits the mean thicknesses of ice floes to between 0.4 and $0.7 \mathrm{~m}$. On the other hand, attenuation of surface waves results in a decreasing rate of frazil-ice formation in open-water areas, leading to the development of mainly congelation ice in open leads. Leads are formed primarily by wind-induced divergence of the ice field. Thus, while we expect to find primarily frazil ice in the near ice-edge region, the amount of congelation ice should increase with increasing distance away from the ice edge.

Our observations support this concept: south of $64^{\circ} \mathrm{S}$, both frazil and congelation ice are observed, with congelation ice reaching a significant fraction of the sampled floes (Fig. 2). Our observations demonstrate that the congelation ice is mostly found in relatively thin floes, representing leads, which refroze under calm ocean-surface conditions. The mixed frazil/congelation ice, which mostly represents rafted floes of predominantly frazil and congelation ice, remains relatively sparse to about $67^{\circ} \mathrm{S}$. Between $68^{\circ}$ and $70^{\circ} \mathrm{S}$, the ice observations showed increased rafting and ridging activities in this southern, near-coastal region of the cruise track. In this area, the amount of mixed frazil/congelation ice increases relative to the other regions of this leg, while the relative proportions of frazil and congelation ice remained approximately equal to those of the adjacent northern ice pack. Rafting of floes of different ice types is also evident in some of our sampled ice cores. Here, we see unusual distributions of textural units caused mainly by re-positioning of parts of the rafted floes (Fig. 5)

In summary, the map of ice-type distribution (Fig. 2) basically reflects the development cycle of Antarctic sea ice, as seen in the Weddell Sea. In conjunction with the

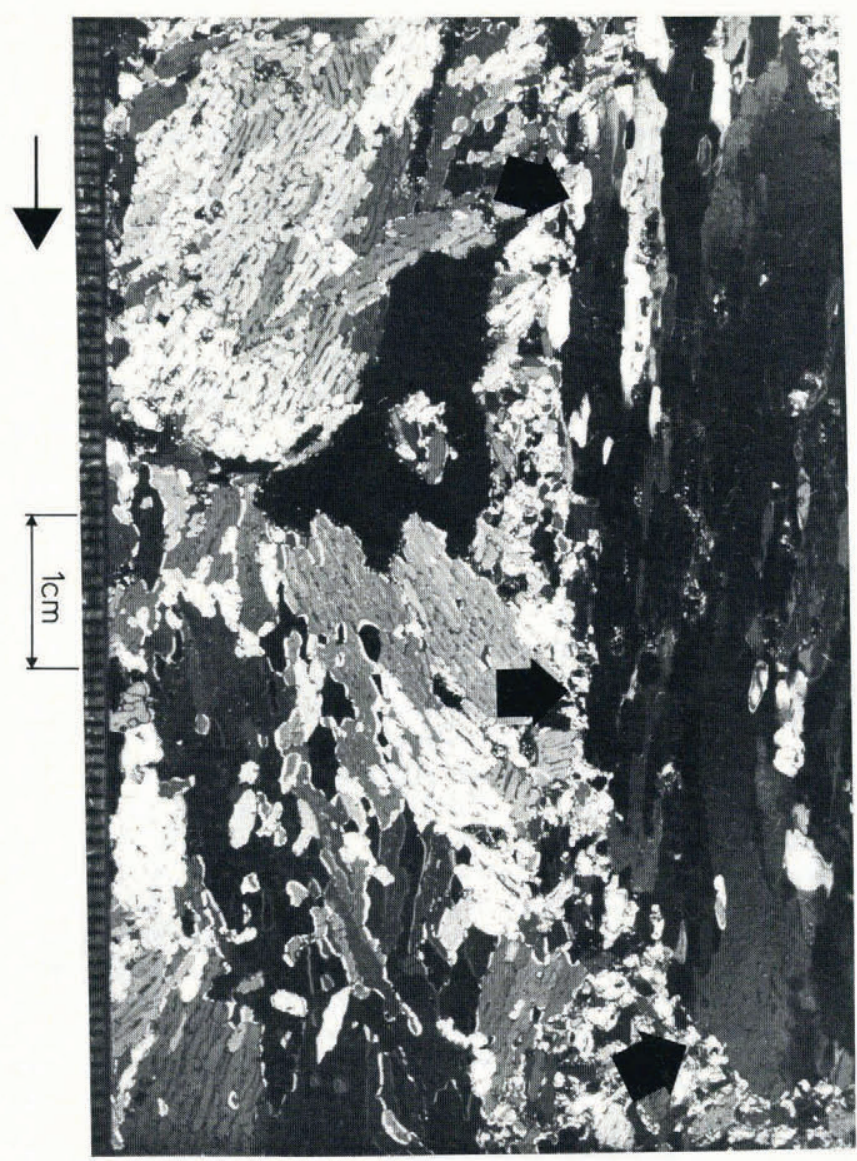

Fig. 5. Vertical thin-section photograph of part of an ice core retrieved from a rafted floe as seen between crossed polarizers; note the "mylonitization zone" at the contact between the two originally separate floes (heavy arrows in the figure). 
ice-thickness data (Wadhams and others, 1988), our observations demonstrate that pancake-ice formation and the pancake-ice cycle represent the major processes of the advancing sea-ice edge in the central Weddell Sea. While congelation ice contributes increasingly to the ice cover with increasing distance from the northern ice edge and mixed frazil/congelation ice appears in highly convergent coastal areas, congelation-ice growth is less dominant in the Antarctic than observed in most parts of the Arctic oceans.

\section{Leg 2 coastal area of eastern Weddell Sea}

On leg 2, the main emphasis was to look at the process in the coastal regime of the eastern Weddell Sea Based on passive microwave and other satellite observations (Zwally and others, 1983), it is known that in the regions close to the ice-shelf edges coastal polynyas frequently develop in the winter months. They are up to several kilometers wide and up to several tens of kilometers long, and remain ice-free for variable periods of time before they refreeze. They eventually re-appear, if wind and ocean conditions are favorable.

On the inbound track of leg 2 , we again sampled the ice cover of the central Weddell Sea, beginning at approximately $58^{\circ} \mathrm{S}$. The ice properties observed on the way south to the continent resembled those seen during the previous leg, with most of the floes consisting of frazil ice and ranging in thickness from about 0.5 up to $2.5 \mathrm{~m}$ near the coastal region.

On the outbound track, melting and disintegration of the pack-ice cover was evident. The strongest indication for this was the well-defined, smooth bottom surface of a number of floes, observed by a remotely controlled underwater vehicle, which was equipped with a video camera allowing inspection of the under-ice regime (Marschall, in press). Strong indications for increased desalination were also seen, mainly in the form of enlarged brine channels. The floe thicknesses in the northern parts of the pack-ice zone ranged from about 0.3 to $0.6 \mathrm{~m}$, which is in agreement with the observations on the first leg (Wadhams and others, 1988). However, the ice cover at this point was already largely broken up, and consisted mainly of bands of ice floes, some several tens of meters wide, interspersed by areas of open water of approximately equal dimensions (Eicken and others, 1988).

Most of our observations and station work were done in the coastal region of the eastern Weddell Sea from 12 October to 28 November. During this time, the ice cover was highly variable, being mostly characterized by the formation and disappearance of coastal polynyas. They formed mainly in response to strong offshore winds and mild surface temperatures. Subsequent cooling led on the one hand to the formation of grease and pancake ice and to smooth sheets of nilas (mostly of congelation ice) on the other, depending on the wind and wave activity at the time of ice formation. The ice thus formed was consequently either mainly frazil ice or congelation ice, with thicknesses between 0.2 and $0.8 \mathrm{~m}$. The ice in the refrozen polynas frequently underwent rafting (finger rafting), thus giving rise to new open-water areas, which however quickly refroze. Changes from offshore winds to onshore winds were the main cause of the closing of the polynyas, which was associated with heavy ridging and rafting of the ice in the polynya.

Observations with the under-water vehicle beneath the near-shore (land-fast) sea ice (Marschall, in press) frequently revealed thick layers of ice platelets up to $5 \mathrm{~m}$ in thickness. The ice platelets were mostly loosely connected with each other and were up to several centimeters in diameter and a few millimeters in thickness. Textural analysis of cores retrieved from adjacent floes (Fig. 6) revealed layers of consolidated platelet ice up to $0.5 \mathrm{~m}$ in thickness, contributing between 10 and $50 \%$ of the entire floe thickness (Eicken and others, 1988; Lange, 1988; paper in preparation by J. Kipfstuhl and others). The under-ice platelet layer and, correspondingly, the floes containing platelet ice extended out from the ice-shelf edges up to about $35 \mathrm{~km}$. Thus, we conclude that the consolidation of ice platelets into solid platelet ice represents a significant mechanism of sea-ice formation in the coastal regions of the Weddell Sea. This is also evident in sea-ice cores sampled during earlier summer expeditions in the same area

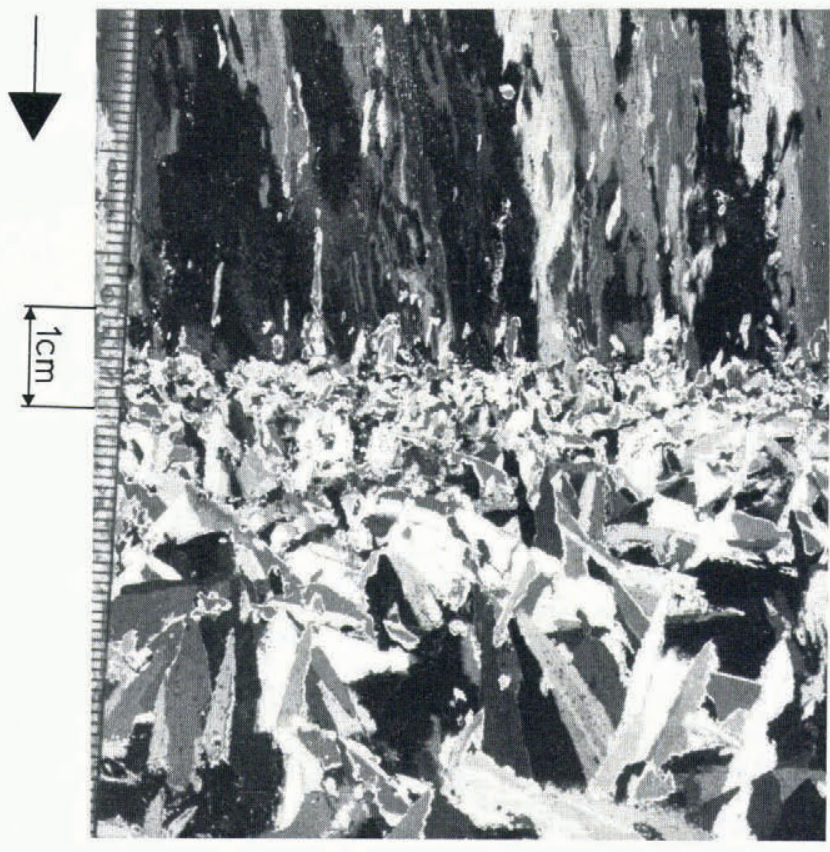

Fig. 6. Vertical thin-section photograph showing the lower part of an ice core taken on a floe, which was previously underlain by a layer of ice platelets; the irregular texture in the bottom half of the image represents a consolidated part of this layer, which we call "platelet ice".

(Lange, 1988; paper in preparation by J. Kipfstuhl and others). Also on the basis of these results, it is concluded that the platelet ice represents about $30 \%$ of the total ice thickness in the near ice-shelf-edge regime of the Weddell Sea, with the remaining $70 \%$ equally divided between frazil and congelation ice.

\section{CONCLUSIONS}

Observations of sea-ice properties during WWSP 86 in the central deep ocean and eastern coastal regimes of the Weddell Sea allow an assessment of basic processes contributing to the growth and development of Antarctic sea ice. Our results demonstrate the importance of dynamic over thermodynamic processes associated with the evolution of a sea-ice cover. A major finding of our study is the fact that large proportions of the growing sea-ice cover are derived by the "pancake cycle", a sequence of processes leading to a rapid formation of $0.5-0.6 \mathrm{~m}$ of ice. A prerequisite for this process is the relatively close proximity to the ic edge, which allows ocean waves to penetrate into the pack, thus leading to new pancake-ice formation in open-water areas created by wave action, rafting, and wind-induced divergence. Once the ice thickness reaches $0.5-0.6 \mathrm{~m}$, opening events occur less frequently, mainly because the distance to the ice edge at this point in the developmental cycle has increased to an amount that most of the wave energy is damped out by the existing ice cover. Thus, we conclude that the mean ice thickness of about $0.5-0.7 \mathrm{~m}$, observed for the greatest part of leg 1 of WWSP 86 (Wadhams and others, 1988) is derived primarily by the formation of pancake ice.

The importance of the "pancake cycle" lies not only in the fact that it allows growth of substantial sea-ice cover in a relatively short time span (up to a few weeks), but also in the fact that most of the sea-ice growth occurs basically at the "open-water" growth rate. This implies that significantly more energy is transferred from the ocean to the atmosphere via the ice growth than can be achieved by congelation-ice growth. This has a bearing on attempts to model the evolution of sea ice in the Weddell Sea, which so far have not taken the "pancake cycle" into account (e.g. Hibler and Ackley, 1983). The "pancake cycle" also explains to a large degree the previously noticed predominance of frazil ice in the Weddell Sea sea ice (e.g. 
Gow and others, 1987). Thus, even though the overall abundances of frazil versus congelation ice in the study of Gow and others (1987) and this study are virtually identical, we hypothesize that the major reason for this distribution is to be found in the pancake-ice formation rather than in the multiple mechanisms previously invoked.

Sea-ice development in the coastal regime during the winter months is dominated by formation and disappearance of coastal polynyas, which essentially result in continuous ice production and advection of this ice northward. The ice produced consists either of mainly frazil or congelation ice, depending on wind and wave activity during growth.

In addition to these two genetic ice classes, we encountered an additional ice type, which has been described previously (Paige, 1966; Lange, 1988; paper in preparation by J. Kipfstuhl and others) and which is called platelet ice. The occurrence of platelet ice in close proximity to the ice-shelf edges suggests that oceanic processes beneath the ice shelf, i.e. supercooling of water due to melting of ice at its bottom surface, are responsible for ice-platelet production (Lewis and Perkin, 1987). Lewis and Perkin (1985) showed that supercooling of surface water occurs in front of the Ross Ice Shelf. They also showed, on the basis of a detailed temperature-salinity profile in the upper $15 \mathrm{~m}$ of the water column beneath existing sea ice (their fig. 10), that the supercooled water regains heat towards the water-ice interface. Simultaneously, salinities increase at the same depths. This is an indication of under-water ice formation as seen in our cores. Under-water ice may also be formed at greater depths (Dieckmann and others, 1986) and rise to the surface, thus also possibly contributing to platelet-ice growth.

Direct visual observations, achieved by the use of a remotely controlled under-water vehicle, revealed the existence of ice-platelet layers up to $5 \mathrm{~m}$ in thickness and up to $35 \mathrm{~km}$ away from the ice-shelf edge. Our textural analysis has demonstrated that a fraction of this platelet layer becomes incorporated into the already existing sea-ice cover, contributing to up to $30 \%$ of the total ice thickness. Thus, a substantial fraction of the near-coastal sea-ice cover arises due to the under-ice platelet layer, again demonstrating that congelation growth might be less important for overall sea-ice growth in the Antarctic compared with the Arctic.

\section{ACKNOWLEDGEMENTS}

We should like to thank the organizers of the Winter Weddell Sea Project 1986 and the Alfred-Wegener-Institut für Polar- und Meeresforschung for the opportunity of participating in this project. We very much thank all the people involved in the field and laboratory work of this study, particularly P. Mursch, M. Scheduikat, and U. Vogel, and the crew of RV Polarstern during both legs of WWSP 86. Helpful suggestions by two anomymous reviewers are greatly appreciated. S.F. Ackley is supported by U.S. National Science Foundation grant DPP 85-12728, and P. Wadhams by U.K. Natural Environment Research Council grant GR3/5713A. M.A.L. would like to thank the Deutsche Forschungsgemeinschaft, who supported attendance at the International Glaciological Society symposium in Hobart where this paper was presented. This is contribution No. 85 of the Alfred-Wegener-Institut für Polar- und Meeresforschung.

\section{REFERENCES}

Ackley, S.F. 1981. A review of sea-ice weather relationships in the Southern Hemisphere. Association of Hydrological Sciences Publication 131 (Symposium at Canberra 1979 - Sea Level, Ice and Climatic Change), 127-159.

Ackley, S.F., P. Wadhams, M.A. Lange, and V. Squire. 1986. Processes of the Antarctic ice edge advance cycle. [Abstract.] EOS, 67(44), 1005.

Casarini, M.P. and R. Massom, eds. 1987. Winter Weddell Sea Project; sea ice observations, leg 1: June-September 1986. Cambridge, University of Cambridge. Scott Polar Research Institute.

Clarke, D.B. and S.F. Ackley, 1984. Sea ice structure and biological activity in the Antarctic marginal ice zone. $J$. Geophys. Res., 89(2), 2087-2095.

Dieckmann, G.S., G. Rohardt, H. Hellmer, and J. Kipfstuhl. 1986. The occurrence of ice platelets at $250 \mathrm{~m}$ depth near the Filchner Ice Shelf and its significance for sea ice biology. Deep-Sea Res., Pt. A, 33(2), 141-148.

Eicken, H., T.C. Grenfell, and B. Stonehouse. 1988. Sea ice conditions during an early spring voyage in the eastern Weddell Sea, Antarctica. Polar Rec., 24(149), 49-54.

Garrison, D.L., C.W. Sullivan, and S.F. Ackley. 1986. Sea ice microbial communities in Antarctica. BioScience, 36(4), 243-250.

Gow, A.J., S.F. Ackley, K.R. Buck, and K.M. Golden. 1987. Physical and structural characteristics of Weddell Sea pack ice. CRREL Rep. 87-14.

Hibler, W.D., III and S.F. Ackley. 1983. Numerical simulation of the Weddell Sea pack ice. J. Geophys. Res., 88(C5), 2873-2887.

Lange, M.A. 1988. Basic properties of Antarctic sea ice as revealed by textural analysis of ice cores. Ann. Glaciol., 10, 95-101.

Lange, M.A., S.F. Ackley, and G.S. Dieckmann. 1986. Development of first year sea ice in the Weddell Sea. [Abstract.] EOS, 67(44), 1005.

Lewis, E.L. and R.G. Perkin. 1985. The winter oceanography of McMurdo Sound, Antarctica. In Jacobs, S.S., ed. Oceanology of the Antarctic continental shelf. Washington, DC, American Geophysical Union, 145-165. (Antarct. Res. Ser., 43.)

Lewis, E.L. and R.G. Perkin. 1986. Ice pumps and their rates. J. Geophys. Res., 91(C10), 11756-11762.

Marschall, H.-P. In press. The overwintering strategy of Antarctic krill under pack-ice. Polar Biol.

Paige, R.A. 1966. Crystallographic studies of sea ice in McMurdo Sound, Antarctica. Port Hueneme, CA, U.S. Naval Civil Engineering Laboratory. (Tech. Rep. R494.)

Squire, V.A., P. Wadhams, and S.C. Moore. 1986. Surface gravity wave processes in the winter Weddell Sea. [Abstract.] EOS, 67(44), 1005.

Wadhams, P., M.A. Lange, and S.F. Ackley. 1987. The ice thickness distribution across the Atlantic sector of the Antarctic Ocean in midwinter. J. Geophys. Res., 92(C13), 14535-14552.

Weeks, W.F. and S.F. Ackley. 1982. The growth, structure and properties of sea ice. CRREL Monogr. 82-1.

Zwally, H.J., J.C. Comiso, C.L. Parkinson, W.J. Campbell, F.D. Carsey, and P. Gloersen. 1983. Antarctic sea ice, 1973-1976: satellite passive-microwave observations. Washington, DC, National Aeronautics and Space Administration. (NASA SP-459.) 